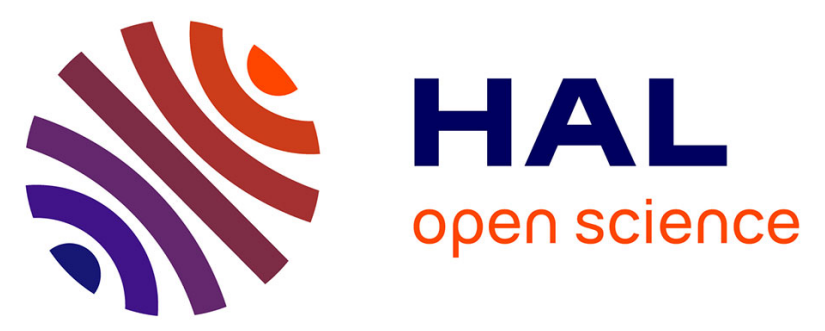

\title{
A circulating subset of BRAFV600E-positive cells in infants with high-risk Langerhans cell histiocytosis treated with BRAF inhibitors
}

Rita Poch, Solenne Le Louet, Zofia Hélias-Rodzewicz, Nawa Hachem, Geneviève Plat, Mohamed Aziz Barkaoui, Hélène Lapillonne, François

Delhommeau, Jean François J.F. Emile, Jean Donadieu, et al.

\section{To cite this version:}

Rita Poch, Solenne Le Louet, Zofia Hélias-Rodzewicz, Nawa Hachem, Geneviève Plat, et al.. A circulating subset of BRAFV600E-positive cells in infants with high-risk Langerhans cell histiocytosis treated with BRAF inhibitors. British Journal of Haematology, 2021, 194 (4), pp.745-749. 10.1111/bjh.17721 . hal-03401846

\section{HAL Id: hal-03401846 \\ https://hal.science/hal-03401846}

Submitted on 10 Dec 2021

HAL is a multi-disciplinary open access archive for the deposit and dissemination of scientific research documents, whether they are published or not. The documents may come from teaching and research institutions in France or abroad, or from public or private research centers.
L'archive ouverte pluridisciplinaire HAL, est destinée au dépôt et à la diffusion de documents scientifiques de niveau recherche, publiés ou non, émanant des établissements d'enseignement et de recherche français ou étrangers, des laboratoires publics ou privés. 
A circulating subset of $B R A F^{\mathrm{V} 600 \mathrm{E}}$-positive cells in infants with high-risk Langerhans cell histiocytosis treated with BRAF inhibitors

\section{AUTHORS}

Rita Poch ${ }^{1}$, Solenne Le Louet ${ }^{1}$, Zofia Hélias-Rodzewicz ${ }^{2,3}$, Nawa Hachem ${ }^{1}$, Geneviève Plat ${ }^{4}$, Mohamed-Aziz Barkaoui ${ }^{5}$, Hélène Lapillonne ${ }^{1}$, François Delhommeau ${ }^{1}$, Jean-François Emile $^{2,3}$, Jean Donadieu ${ }^{1,2,5}$, Sébastien Héritier ${ }^{1,5}$

\section{AFFILIATIONS}

1 Sorbonne Université, INSERM, Centre de Recherche Saint-Antoine, CRSA, F-75012, Paris, France

2 EA4340-BECCOH, Versailles SQY University, Boulogne, France

3 Pathology department, Ambroise Paré Hospital, AP-AP, Boulogne, France

4 Department of Pediatric Hematology and Oncology, Centre Hospitalo-Universitaire de Toulouse, France

5 French Reference Center for Langerhans Cell Histiocytosis, Department of Pediatric Hematology and Oncology Trousseau Hospital, AP-AP, Paris, France

\section{CORRESPONDING AUTHOR}

Sébastien Héritier, MD, PhD

French Reference Center for Langerhans Cell Histiocytosis, Trousseau Hospital, 26 avenue du Dr Netter, 75012 Paris, France.

E-mail: sebastien.heritier@aphp.fr

Phone: 0033 171738717; Fax: 0033144736573

Running title: $B R A F^{\mathrm{V} 600 \mathrm{E}}$-positive circulating cells in $\mathrm{LCH}$

\section{BRIEF REPORT}

Abstract: 100/100 words

Text: 1498/1500 words

1 table, 1 figure

\section{Additional file}




\begin{abstract}
BRAF inhibitors effectively treat $B R A F^{\mathrm{V} 600 \mathrm{E}}$-mutated, risk-organ-positive Langerhans cell histiocytosis $(\mathrm{RO}+\mathrm{LCH})$. However, cell-free $B R A F^{\mathrm{V} 600 \mathrm{E}}$ DNA often persists during therapy and recurrence frequently occurs after therapy discontinuation. To identify a pathological reservoir of $B R A F^{\mathrm{V} 600 \mathrm{E}}$-mutated cells, we studied peripheral blood cells obtained from 6 infants with RO+ MS LCH that received targeted therapy. After cell sorting, the $B R A F^{\mathrm{V} 600 \mathrm{E}}$ mutation was detected in monocytes $(n=5)$, B lymphocytes $(n=3)$, T lymphocytes $(n=2)$, and myeloid and plasmacytoid dendritic cells $(\mathrm{n}=2$ each). This biomarker may offer an interesting tool for monitoring the effectiveness of new therapeutic approaches for weaning children with RO+ LCH from targeted therapy.
\end{abstract}

Keywords: Langerhans cell histiocytosis, biomarker, BRAF, targeted therapy, circulating tumor cells 


\section{MANUSCRIPT}

Children with refractory $B R A F^{\mathrm{V} 600 \mathrm{E}}$-mutated, risk-organ-positive, multisystem Langerhans cell histiocytosis (RO+ MS LCH) benefit from targeted therapy with BRAF inhibitors, like vemurafenib and dabrafenib (Donadieu et al, 2019; Eckstein et al, 2019; Kieran et al, 2019; Lee et al, 2020). However, recurrences frequently occur upon weaning from this targeted therapy. Importantly, during therapy, and despite a clinical complete remission, patients maintain a persistent positive $B R A F^{\mathrm{V} 600 \mathrm{E}}$ allelic load, when measured in circulating cell-free (ccf) DNA (Donadieu et al, 2019; Schwentner et al, 2019). These data suggested that a pathological cell reservoir persisted. Recent studies have suggested that, particularly in young infants with $\mathrm{RO}+\mathrm{MS} \mathrm{LCH}$, the clonal origin of the pathological $B R A F^{\mathrm{V} 600 \mathrm{E}}$ mutated histiocytes may originate from hematopoietic stem cells. One argument in favor of this hypothesis is that, in addition to the pathological CD1a+CD207+ histiocytes of the lesions, other cells carry the $B R A F^{\mathrm{V} 600 \mathrm{E}}$ mutation, including monocytes, myeloid dendritic cells (mDCs), plasmacytoid dendritic cells (pDCs), and less frequently, B and T lymphocytes (Berres et al, 2015; Milne et al, 2017; Xiao et al, 2020). However, previous studies have included very low numbers of patients, and the kinetics of these sub-sets of $B R A F^{\mathrm{V} 600 \mathrm{E}}$-mutated circulating blood cells during the natural course of the disease remains unknown. To prepare for a prospective study that would systematically follow the sub-sets of $B R A F^{\mathrm{V} 600 \mathrm{E}}$-mutated circulating blood cells in infants treated for RO + MS LCH, we conducted the present study to assess feasibility. For this study, we identified 6 infants with RO+ MS LCH from a French cohort of patients with LCH that were treated with vemurafenib (Donadieu et al, 2019). We acquired stored frozen samples of peripheral blood mononuclear cells (PBMCs) that were drawn from each patient during vemurafenib therapy or after discontinuing therapy. This study was approved by the Ile de France III Ethics Committee (\#2011-A00447-34), and it was conducted in accordance with the principles of the Declaration of Helsinki. Written informed consent was obtained from the parents of all children.

The 6 studied patients (Table I) were infants, with a median age at diagnosis of 0.7 years (range, 0.1 to 1.3 years). All patients had $B R A F^{\mathrm{V} 600 \mathrm{E}}$-mutated $\mathrm{RO}+\mathrm{MS} \mathrm{LCH}$. The organs involved, in order of descending frequency, were: skin $(n=6)$, hematology $(n=6)$, bone $(n=2)$, liver $(n=2)$, spleen $(n=2)$, and gut $(n=1)$. For these patients, vemurafenib was given after failure of the firstline treatment of vinblastine combined with corticosteroid therapy $(n=6)$ and 2-chlorodeoxyadenosine (2CDA, $n=1$; patient 6 , who had no active hematologic involvement at the time). For this patient, 2CDA monotherapy was administered after progression at month 
9 of the combined vinblastine-steroid treatment, but 3 courses of 2CDA were ineffective with progression to RO, then vemurafenib was started 13.5 months after the initial diagnosis. The median time from diagnosis to the initiation of vemurafenib was 7.3 months (range, 1.1 to 13.5 months), and the median age when starting vemurafenib was 1.3 years (range, 0.2 to 1.9 years). The median Disease Activity Score (Donadieu et al, 2004) at the start of treatment was 7.5 (range, 3 to 14). Vemurafenib was crushed and dissolved in water or milk for oral administration, as previously described (Héritier et al, 2015; Donadieu et al, 2019). The median dose was $23 \mathrm{mg} / \mathrm{kg} /$ day (range, 20 to $24 \mathrm{mg} / \mathrm{kg} /$ day). The median residual plasma vemurafenib concentration, measured at steady state, was $14 \mathrm{mg} / \mathrm{L}$ (range, 8.7 to $20.2 \mathrm{mg} / \mathrm{L}$ ). In all patients, a complete clinical response was achieved rapidly after vemurafenib initiation.

All patient except P6 underwent longitudinal monitoring of the ccf $B R A F^{\mathrm{V} 600 \mathrm{E}}$ plasmatic load during treatment, as previously described (Héritier et al, 2017). The monitoring results showed persistent detection of ccf $B R A F^{\mathrm{V} 600 \mathrm{E}}$ during treatment. The median plasmatic load was $3.5 \%$ (range, 1.1 to $12.8 \%$ ), measured at the start of vemurafenib, and $2.1 \%$ (range, 1.2 to $4.1 \%$ ), measured after 9 months of continuous therapy (Fig. 1A). For 3 patients (P4, P5, and P6), treatment was discontinued, and reactivations occurred after 7 days (P5), 2 months (P4), and 8 months (P6). At reactivation, ccf $B R A F^{\mathrm{V} 600 \mathrm{E}}$ plasmatic load was $3.9 \%$ for $\mathrm{P} 5,3.1 \%$ for $\mathrm{P} 6$, and was not available for P4. All 6 patients were taking vemurafenib at the last visit.

For each patient, we studied a sample of frozen PBMCs, obtained at different times during the clinical course. For P1, P2, and P3, respectively, PBMCs were collected on day 15, at 5 months, and at 9 months from the start of vemurafenib treatment. For P4, P5, and P6, the PBMCs were collected after attempting to discontinue the targeted therapy. Thus, PBMCs were collected at 7 days after discontinuation, for P4 and P5, and at 8 months after discontinuation for P6. At the time of collection, P5 and P6 showed LCH reactivation, but all other patients were in complete clinical remission.

After thawing and immunostaining, the PBMCs were sorted with flow cytometry (Influx, Beckton-Dickinson, Le Pont-de-claix, France) to isolate 5 sub-populations of interest: monocytes, pDCs, mDCs, B lymphocytes, and T lymphocytes (Fig. 1B and Supplemental file 1). We extracted DNA from each sorted subpopulation, then we analyzed the DNA with realtime quantitative TaqMan PCR (qPCR) assays for $B R A F^{\mathrm{V} 600 \mathrm{E}}$, as previously described (HéliasRodzewicz et al, 2015). Based on the PCR results, we estimated the percentage of mutated $B R A F^{\mathrm{V} 600 \mathrm{E}}$ cells in each sorted subpopulation (Supplemental file 2). With this method, the limit of detection was a variant allele frequency (VAF) of $1 \%$, for the three largest 
subpopulations among the PBMCs (i.e., monocytes, B lymphocytes, and T lymphocytes), and a VAF of 5\% for the smaller subpopulations (pDCs and mDCs). Due to insufficient amounts of cells, we could not perform subsequent analyses on mDCs for 3 patients, pDCs for 2 patients, and monocytes for 1 patient. When the $B R A F^{\mathrm{V} 600 \mathrm{E}}$ allele was detectable, but the VAF was close to the limit of detection, we confirmed the result with digital PCR (Supplemental file 3).

All patients carried $B R A F^{\mathrm{V} 600 \mathrm{E}}$ in PBMCs, but the subsets of cells positive for $B R A F^{\mathrm{V} 600 \mathrm{E}}$ were different among patients, and the $\mathrm{VAF}$ was variable (Fig. 1C). The $B R A F^{\mathrm{V} 600 \mathrm{E}}$ mutation was detected in the monocytes of all 5 patients analyzed; the mean proportion of mutated cells was $10 \%$ (range: $2-30 \%$ ). For 3 and 2 patients, the $B R A F^{\mathrm{V} 600 \mathrm{E}}$ mutation was detectable in $\mathrm{B}$ and $\mathrm{T}$ lymphocytes, respectively. The mean proportions of mutated cells were 9\% (range: 2-16\%) among B lymphocytes and 3\% (range: 2-4\%) among T lymphocytes. Among the 4 patients analyzed for $\mathrm{pDCs}$ and the 3 patients analyzed for $\mathrm{mDCs}, 2$ had $B R A F^{\mathrm{V} 600 \mathrm{E}}$-positive $\mathrm{mDCs}$ (24\% mDCs for P1 and $16 \% \mathrm{mDCs}$ for P3), and 2 had $B R A F^{\mathrm{V} 600 \mathrm{E}}$-positive pDCs (20\% pDCs for both $\mathrm{P} 1$ and $\mathrm{P} 3$ ). Two patients, $\mathrm{P} 1$ and $\mathrm{P} 3$, that had the highest ccf $B R A F^{\mathrm{V} 600 \mathrm{E}}$ DNA levels (above $10 \%$ ) at initiation of vemurafenib therapy also had the most $B R A F^{\mathrm{V} 600 \mathrm{E}}$-positive subpopulation and at the higher level. Both these patients were in clinical complete remission at the time of PBMC collection. The samples were collected after 15 days (P1) and after 9 months (P3) of targeted therapy. The 4 other patients showed positivity in one or 2 subpopulations, but the other subpopulations were too small for analysis. Importantly, for the 3 patients that had completed therapy, the persistence of mutated cells among PBMCs was associated with reactivations that were either clinically detectable (P5 and P6) or imminent (P4) at the time of PBMC collection.

These results showed that, in children with severe $\mathrm{RO}+\mathrm{MS} \mathrm{LCH}$, the $B R A F^{\mathrm{V} 600 \mathrm{E}}$ mutation was present, both in pathological CD1a + CD207 + histiocytes within the lesions and in other hematopoietic cell subtypes of myeloid and lymphoid lineages. The advantage of our analysis over a plasmatic ccf $B R A F^{\mathrm{V} 600 \mathrm{E}} \mathrm{DNA}$ analysis, was that our analysis provided information about the $B R A F$ allele distribution among various cellular compartments. On the other hand, our analysis was more expensive and tedious than a ccf DNA analysis, due to cell sorting and the molecular analysis of each population sorted. We chose the $B R A F^{\mathrm{V} 600 \mathrm{E}} \mathrm{qPCR}$ assay, because it was inexpensive, easy to perform in any hematology center, and its limit of detection was relatively low (down to $1 \%$ ) for analyzing the cell subgroups most represented in PBMCs. 
Beyond the general interest in $B R A F^{\mathrm{v} 600 \mathrm{E}}$ mutations and the debate on the stage of maturation of the cell responsible for the RO+ MS LCH, our study will encourage others to perform this type of analysis, both at diagnosis and in longitudinal follow-ups, for patients treated for LCH with cytotoxic chemotherapy or targeted therapies. Indeed, in $\mathrm{RO}-$ and $\mathrm{RO}+\mathrm{LCH}$, respectively, $4 \%$ and $49 \%$ of patients did not respond to vinblastine-corticosteroid therapy, and $38 \%$ experienced reactivation, particularly those treated for $B R A F^{\mathrm{V} 600 \mathrm{E}}$-mutated $\mathrm{LCH}$ (Héritier et al, 2016). Among patients treated with 2-chlorodeoxyadenosine, $34 \%$ of patients with RO- did not respond or experienced reactivation (Barkaoui et al, 2020). The demonstration of a circulating subpopulation of cells that are resistant to treatment may be evaluated in a prospective, consistent patient cohort, to identify whether a mutated cell profile and its persistence might be associated with a particular clinical pattern or outcome. Moreover, future studies may investigate whether a therapeutic adaptation could be considered, based on the persistent $B R A F^{\mathrm{V} 600 \mathrm{E}}$ sub-population.

\section{ACKNOWLEDGMENTS}

We would like to thank the patients and their families for their participation in this study. This study was supported by a grant (\#11413) from the Conquer Cancer Foundation ASCO Young Investigator Award, funded by the Strike 3 Foundation. This study received grants from the Société Française de lutte contre les Cancers de l'Enfant et de l'Adolescent; the Fédération Enfants et Santé; the Association Recherche et Maladie Hématologiques de l'Enfant; the Association Les 111 des Arts de Paris; and the Association la Petite Maison dans la Prairie. This project received ongoing support from the Association Histiocytose France. The French LCH registry was supported by a grant from InVS and INSERM for the rare disease registry. This study was based on research from the Centre de Reference des Histiocytoses (www.histiocytose.org).

\section{AUTHORSHIP CONTRIBUTIONS}

R.P. and S.H. designed the study. J.D. and S.H. obtained funding. M.-A.B, J.D., and S.H. performed monitoring and data control. Patients were managed by S.H., J.D., and G.P. Experiments were performed by R.P., S.L., and Z.H.-R. Data were analyzed by R.P., S.L., Z.H.R, N.H.,H.L., F.D., J.-F.E., and S.H.. All authors read the manuscript critically and approved the final version. 


\section{CONFLICT-OF-INTEREST STATEMENTS}

JD received grants from X4 Pharmaceuticals, outside the submitted work. All other authors declare no competing interests. 


\section{REFERENCES}

Barkaoui, M.-A., Queheille, E., Aladjidi, N., Plat, G., Jeziorski, E., Moshous, D., Lambilliotte, A., Kebaili, K., Pacquement, H., Leverger, G., Mansuy, L., Entz-Werlé, N., Bodet, D., Schneider, P., Pagnier, A., Lutun, A., Gillibert-Yvert, M., Millot, F., Toutain, F., Reguerre, Y., et al (2020) Long-term follow-up of children with risk organ-negative Langerhans cell histiocytosis after 2-chlorodeoxyadenosine treatment. British Journal of Haematology, 191, 825-834.

Berres, M.-L., Lim, K.P.H., Peters, T., Price, J., Takizawa, H., Salmon, H., Idoyaga, J., Ruzo, A., Lupo, P.J., Hicks, M.J., Shih, A., Simko, S.J., Abhyankar, H., Chakraborty, R., Leboeuf, M., Beltrão, M., Lira, S.A., Heym, K.M., Clausen, B.E., Bigley, V., et al (2015) BRAF-V600E expression in precursor versus differentiated dendritic cells defines clinically distinct LCH risk groups. The Journal of Experimental Medicine, 212, 281.

Donadieu, J., Larabi, I.A., Tardieu, M., Visser, J., Hutter, C., Sieni, E., Kabbara, N., Barkaoui, M., Miron, J., Chalard, F., Milne, P., Haroche, J., Cohen, F., Hélias-Rodzewicz, Z., Simon, N., Jehanne, M., Kolenova, A., Pagnier, A., Aladjidi, N., Schneider, P., et al (2019) Vemurafenib for Refractory Multisystem Langerhans Cell Histiocytosis in Children: An International Observational Study. Journal of Clinical Oncology, 37, 2857-2865.

Donadieu, J., Piguet, C., Bernard, F., Barkaoui, M., Ouache, M., Bertrand, Y., Ibrahim, H., Emile, J.F., Hermine, O., Tazi, A., Genereau, T. \& Thomas, C. (2004) A new clinical score for disease activity in Langerhans cell histiocytosis. Pediatric Blood \& Cancer, 43, 770-776.

Eckstein, O.S., Visser, J., Rodriguez-Galindo, C., Allen, C.E., \& NACHO-LIBRE Study Group (2019) Clinical responses and persistent BRAF V600E+ blood cells in children with LCH treated with MAPK pathway inhibition. Blood, 133, 1691-1694.

Hélias-Rodzewicz, Z., Funck-Brentano, E., Baudoux, L., Jung, C.K., Zimmermann, U., Marin, C., Clerici, T., Le Gall, C., Peschaud, F., Taly, V., Saiag, P. \& Emile, J.-F. (2015) Variations of BRAF mutant allele percentage in melanomas. BMC cancer, 15, 497.

Héritier, S., Emile, J.-F., Barkaoui, M.-A., Thomas, C., Fraitag, S., Boudjemaa, S., Renaud, F., Moreau, A., Peuchmaur, M., Chassagne-Clément, C., Dijoud, F., Rigau, V., Moshous, D., Lambilliotte, A., Mazingue, F., Kebaili, K., Miron, J., Jeziorski, E., Plat, G., Aladjidi, N., et al (2016) BRAF Mutation Correlates With High-Risk Langerhans Cell Histiocytosis and Increased Resistance to First-Line Therapy. Journal of Clinical Oncology, 34, 3023-3030.

Héritier, S., Hélias-Rodzewicz, Z., Lapillonne, H., Terrones, N., Garrigou, S., Normand, C., Barkaoui, M.-A., Miron, J., Plat, G., Aladjidi, N., Pagnier, A., Deville, A., GillibertYvert, M., Moshous, D., Lefèvre-Utile, A., Lutun, A., Paillard, C., Thomas, C., Jeziorski, E., Nizard, P., et al (2017) Circulating cell-free BRAFV600E as a biomarker in children with Langerhans cell histiocytosis. British Journal of Haematology, 178, 457-467. 
Héritier, S., Jehanne, M., Leverger, G., Emile, J.-F., Alvarez, J.-C., Haroche, J. \& Donadieu, J. (2015) Vemurafenib Use in an Infant for High-Risk Langerhans Cell Histiocytosis. JAMA oncology, 1, 836-838.

Kieran, M.W., Geoerger, B., Dunkel, I.J., Broniscer, A., Hargrave, D., Hingorani, P., Aerts, I., Bertozzi, A.-I., Cohen, K.J., Hummel, T.R., Shen, V., Bouffet, E., Pratilas, C.A., Pearson, A.D.J., Tseng, L., Nebot, N., Green, S., Russo, M.W. \& Whitlock, J.A. (2019) A Phase I and Pharmacokinetic Study of Oral Dabrafenib in Children and Adolescent Patients with Recurrent or Refractory BRAF V600 Mutation-Positive Solid Tumors. Clinical Cancer Research, 25, 7294-7302.

Lee, L.H., Krupski, C., Clark, J., Wunderlich, M., Lorsbach, R.B., Grimley, M.S., Burwinkel, M., Nelson, A. \& Kumar, A.R. (2020) High-risk LCH in infants is serially transplantable in a xenograft model but responds durably to targeted therapy. Blood Advances, 4, 717727.

Milne, P., Bigley, V., Bacon, C.M., Néel, A., McGovern, N., Bomken, S., Haniffa, M., Diamond, E.L., Durham, B.H., Visser, J., Hunt, D., Gunawardena, H., Macheta, M., McClain, K.L., Allen, C., Abdel-Wahab, O. \& Collin, M. (2017) Hematopoietic origin of Langerhans cell histiocytosis and Erdheim-Chester disease in adults. Blood, 130, $167-175$.

Schwentner, R., Kolenová, A., Jug, G., Schnöller, T., Ahlmann, M., Meister, B., Lehrnbecher, T., Minkov, M. \& Hutter, C. (2019) Longitudinal assessment of peripheral blood BRAFV600E levels in patients with Langerhans cell histiocytosis. Pediatric Research, 85, 856-864.

Xiao, Y., van Halteren, A.G.S., Lei, X., Borst, J., Steenwijk, E., de Wit, T., Grabowska, J., Voogd, R., Kemps, P., Picarsic, J., van den Bos, C. \& Borst, J. (2020) Bone marrowderived myeloid progenitors as driver mutation carriers in high- and low-risk Langerhans cell histiocytosis. Blood, 136, 2188-2199. 


\section{TABLES AND FIGURE}

Table I. Characteristics of patients with RO+ MS LCH treated with vemurafenib

\begin{tabular}{|c|c|c|c|c|c|c|c|c|}
\hline Patient & $\begin{array}{l}\text { Age at } \mathrm{LCH} \\
\text { diagnosis } \\
\text { (years) }\end{array}$ & $\begin{array}{c}\text { Disease } \\
\text { extension } \\
\text { (organs involved) }\end{array}$ & $\begin{array}{c}\text { Age at } \\
\text { vemurafenib } \\
\text { initiation (years) }\end{array}$ & $\begin{array}{c}\text { DAS at } \\
\text { vemurafenib } \\
\text { initiation }\end{array}$ & $\begin{array}{l}\text { Dosage of } \\
\text { vemurafenib } \\
(\mathrm{mg} / \mathrm{kg} \times 2 / \mathrm{d})\end{array}$ & $\begin{array}{c}\text { Median plasma } \\
\text { vemurafenib } \\
\text { concentration (mg/L) }\end{array}$ & $\begin{array}{l}\text { Duration of vemurafenib } \\
\text { administration and status } \\
\text { at PBMC collection }\end{array}$ & $\begin{array}{l}\text { DAS and disease status } \\
\text { at PBMC collection }\end{array}$ \\
\hline P1 & 0.6 & $\begin{array}{l}\text { RO+ MS (skin, } \\
\text { bone, hemato) }\end{array}$ & 1.3 & 6 & 12 & 18.2 & 15 days; on therapy & 0, non-active disease \\
\hline P2 & 0.1 & $\begin{array}{l}\text { MS OR+, (skin, } \\
\text { gut, hemato) }\end{array}$ & 0.2 & 7 & 12 & 14.0 & 5 months; on therapy & 0, non-active disease \\
\hline P3 & 0.8 & $\begin{array}{l}\text { RO+ MS (skin, } \\
\text { hemato, liver, } \\
\text { spleen) }\end{array}$ & 1.6 & 14 & 12 & 20.2 & 9 months; on therapy & 0, non-active disease \\
\hline P4 & 0.2 & $\begin{array}{l}\text { RO+ MS (skin, } \\
\text { hemato) }\end{array}$ & 0.7 & 9 & 10 & 8.7 & $\begin{array}{c}21 \text { months; discontinued } \\
\text { for } 7 \text { days }\end{array}$ & 0, non-active disease \\
\hline P5 & 1.3 & $\begin{array}{l}\text { RO+ MS (skin, } \\
\text { hemato, liver, } \\
\text { spleen) }\end{array}$ & 1.4 & 8 & 11 & 10.2 & $\begin{array}{l}12 \text { months; discontinued } \\
\text { for } 7 \text { days }\end{array}$ & 4 , disease reactivation \\
\hline P6 & 0.8 & $\begin{array}{l}\text { RO+ MS (skin, } \\
\text { bone, hemato) }\end{array}$ & 1.9 & 3 & 11 & - & $\begin{array}{c}2 \text { months; discontinued for } \\
8 \text { months }\end{array}$ & 3 , disease reactivation \\
\hline
\end{tabular}

Abbreviations: RO+ MS, risk-organ positive multisystem; LCH, Langerhans cell histiocytosis; DAS, Disease Activity Score; PBMC, peripheral blood mononuclear cells; hemato: haematological involvement 
Figure 1: Cell-free circulating $B R A F^{\mathrm{v} 600 \mathrm{e}} \mathrm{DNA}$ during the course of RO+ MS LCH and the cells that carry $\mathrm{BRAF}^{\mathrm{v} 600 \mathrm{e}}$. (A) The load of circulating cell-free $B R A F^{\mathrm{V} 600 \mathrm{E}}$ during and after BRAF inhibitor therapy, and the clinical status of each patient at the time of PBMC collection. D0: treatment start; M1-M12, months of treatment; D7 and M8: 7 days and 8 months, respectively, after discontinuation. Patients (P1-P6) are color-coded. (B) Cell sorting strategy to isolate 5 sub-populations of interest: monocytes, $\mathrm{pDCs}, \mathrm{mDCs}, \mathrm{B}$ lymphocytes, and $\mathrm{T}$ lymphocytes. (C) Percentage of $B R A F^{\mathrm{V} 600 \mathrm{E}}$-positive cells among sorted sub-populations and per patient. The grey hatched line represents the limit of detection with our BRAF-specific qPCR method. In subpopulations where $B R A F^{\mathrm{V} 600 \mathrm{E}}$ levels were close to the limit of detection, the result was confirmed with digital PCR. The time of collection of PBMC for each patient is mentioned in Figure 1A. $\mathrm{x}$ : Insufficient numbers in a subpopulation to allow analysis. RO+ MS LCH: risk-organ positive multisystem Langerhans cell histiocytosis; P1-P6: patient numbers; PBMC: peripheral blood mononuclear cells; pDCs: plasmacytoid dendritic cells; mDCs: myeloid dendritic cells 


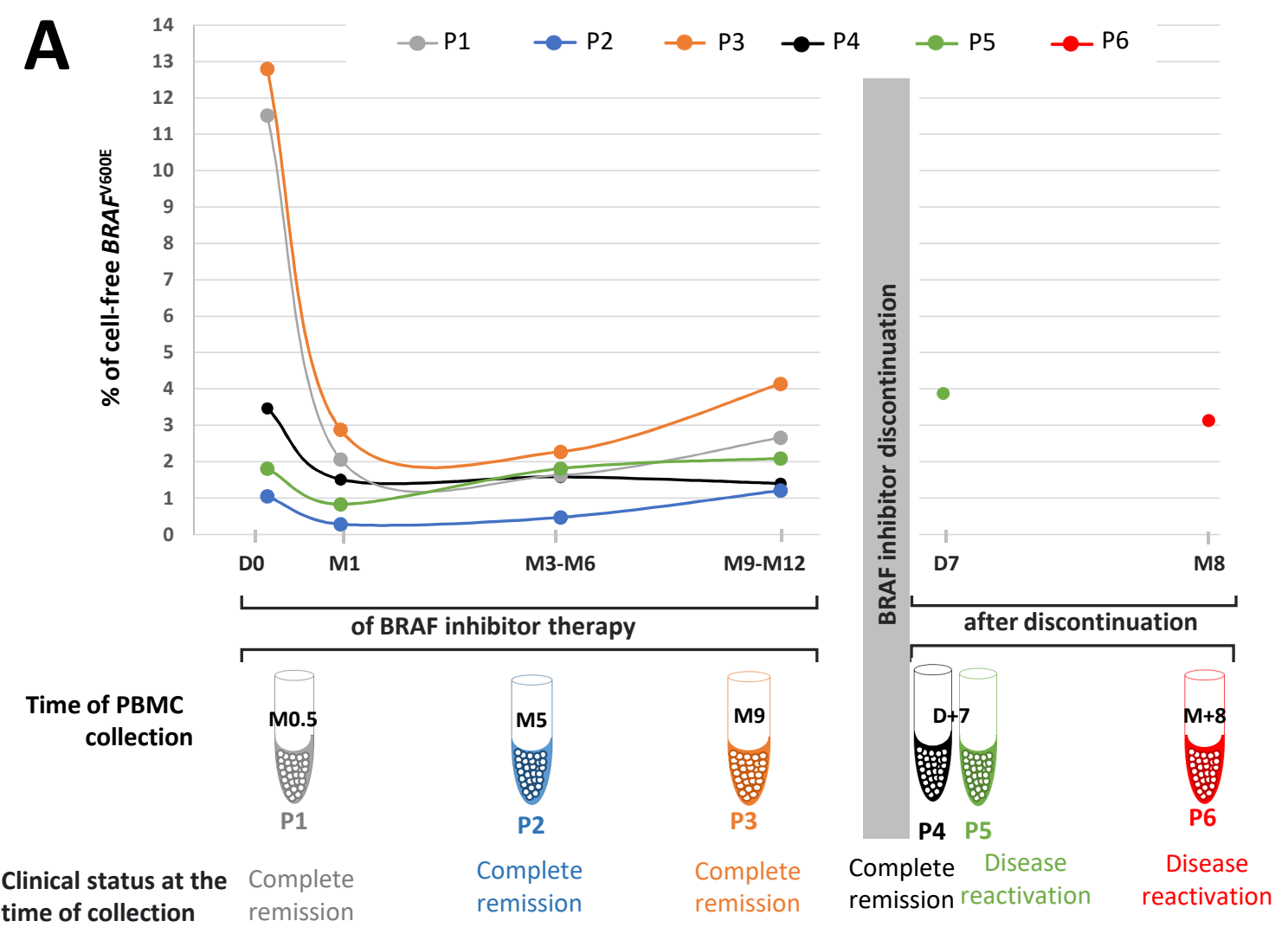

B
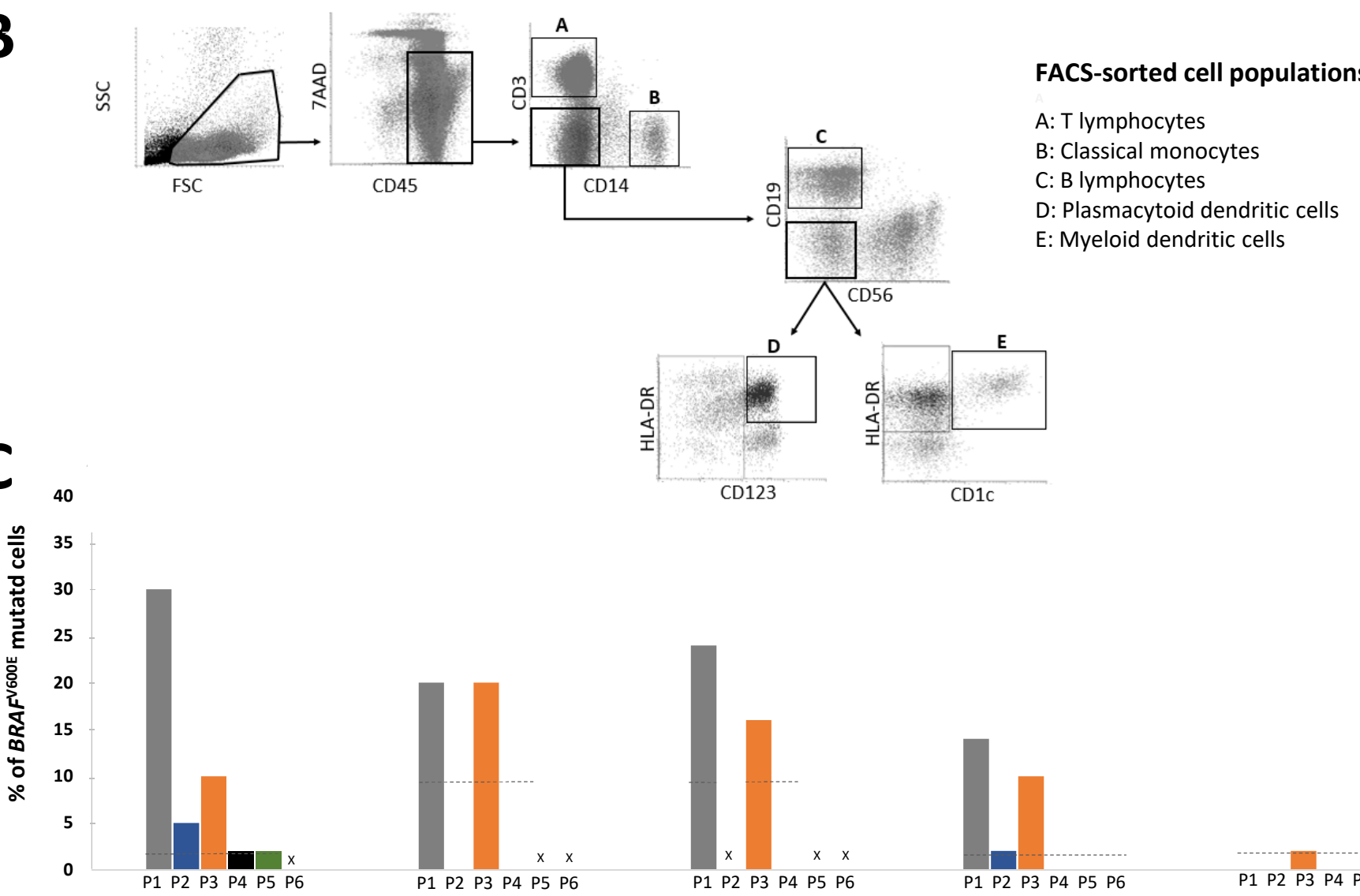

P1 P2 P3 P4 P5 P6

Monocytes pDCs

mDCs

B lymphocytes

T lymphocytes 


\section{SUPPLEMENTAL FILE}

\section{Supplemental file 1: Fluorescence-activated cell sorting}

Antibodies were tagged with fluorescent markers, as follows: antigen fluorochrome (clone) CD45-Krome Orange (J33; Beckman Coulter), CD3-PE (SK7), CD14-FITC (61D3 ; ThermoFisher), CD19-APC-A750 (SJ25-C1; ThermoFisher), CD56-APC (CMSSB; ThermoFisher), CD123-PC7 (6H6 ; ThermoFisher), CD1c-PE Dazzle 594 (L161; Biolegend), HLADR-Pacific Blue (Immu-357; Beckman Coulter), 7 AAD Viability staining (Biolegend).

Flow cytometry panel of antibody targets:

\begin{tabular}{|c|c|}
\hline T lymphocytes & CD45+ 7AAD-CD3+ \\
\hline B lymphocytes & CD45+ 7AAD- CD3- CD14- CD19+ \\
\hline CD14+ monocytes & CD45+ 7AAD- CD3-CD14+ \\
\hline pDCs & CD45+ 7AAD- CD3- CD19- CD56- CD14- HLADR+ CD123+ \\
\hline mDCs & CD45+ 7AAD- CD3- CD19- CD56- CD14- HLADR+ CD1c+ \\
\hline
\end{tabular}

\section{Supplemental file 2: Real-time quantitative TaqMan PCR assays for BRAF ${ }^{\mathrm{v} 600 E}$}

PCR primers and probes are listed below (Table S1) (Hélias-Rodzewicz et al, 2015). PCR amplification and detection were performed on a QuantStudio 3 Real-Time PCR System (Thermofisher Scientific). The protocol had an initial step of $2 \mathrm{~min}$ at $50^{\circ} \mathrm{C}$, followed by 50 cycles of $15 \mathrm{~s}$ at $95^{\circ} \mathrm{C}$ and $90 \mathrm{~s}$ at $60^{\circ} \mathrm{C}$. Commercial wild-type DNA and $B R A F_{V_{6000}-}$ mutated DNA (Horizon DNA) were mixed in various proportions to generate a standard curve of $B R A F_{\mathrm{V} G 000} / B R A F_{\text {total }}$ against $\triangle \mathrm{Ct}\left(\mathrm{Ct}_{\text {BRAFWT }}-\mathrm{Ct}_{\text {BRAFV600E }}\right.$ (Figure $\left.\mathrm{S} 1\right)$. All samples were measured in triplicate, and the mean $\triangle \mathrm{Ct}$ was used to calculate the $B R A F_{\mathrm{v} 600 \mathrm{E}} / B R A F_{\text {total, }}$, as previously described ( Levine et al, 2006; Delhommeau et al, 2007).

Table SI: Oligonucleotides used to detect BRAF V600 in qPCR and digital PCR analyses

\begin{tabular}{|c|c|}
\hline Oligonucleotide type & Sequence \\
\hline Forward Primer & CTACTGTTTTCCTTTACTTACTACACCTCAGA \\
\hline Reverse Primer & ATCCAGACAACTGTTCAAACTGATG \\
\hline Probe for $B R A F$ V600 WT & VIC-CTAGCTACAGTGAAATC \\
\hline Probe for $B R A F$ V600E & 6FAM-TAGCTACAGAGAAATC \\
\hline
\end{tabular}



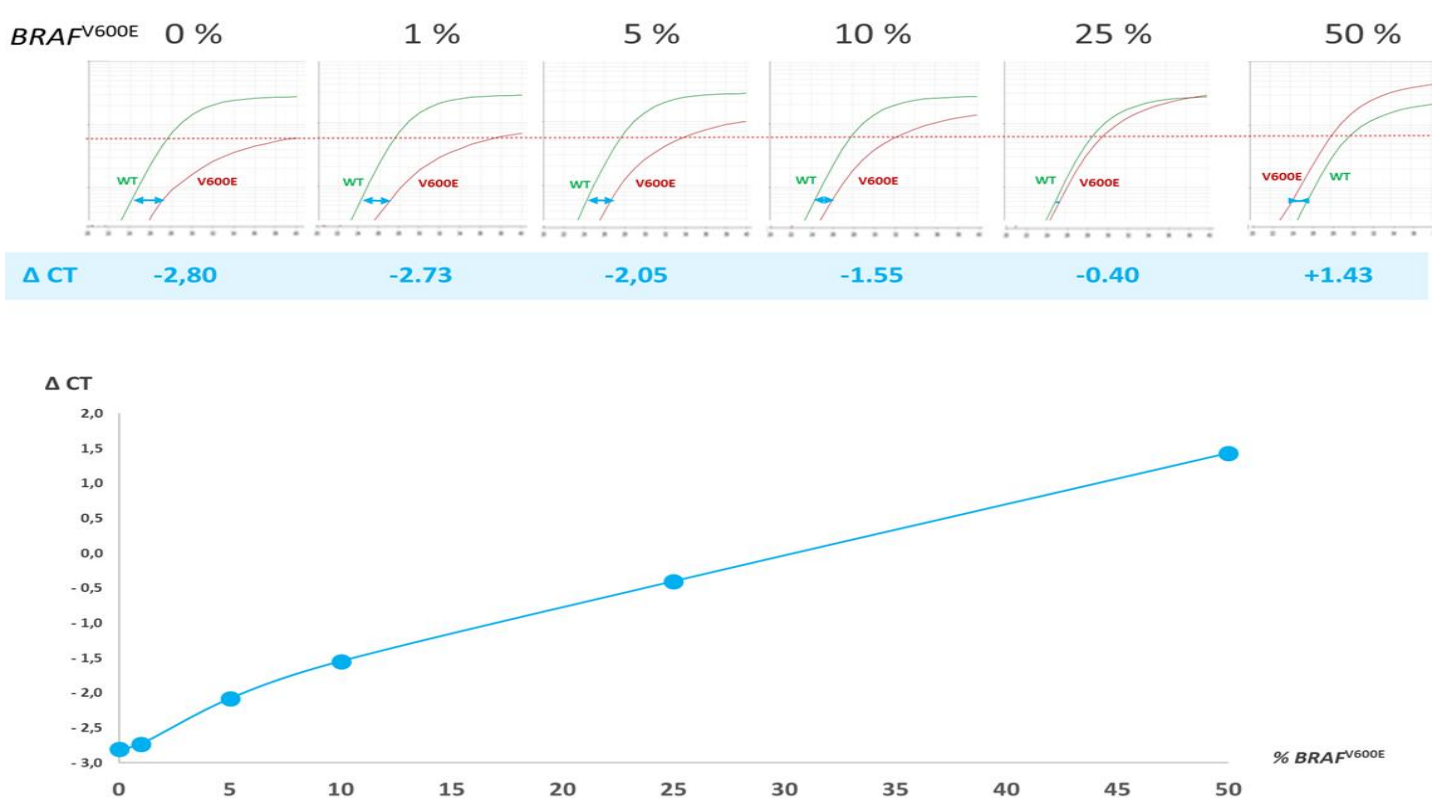

Figure S1: Quantification of the percentage of $B R A F^{V 600 E}$ detected with allele-specific Taqman qPCR, based on the difference in cycle thresholds $(\triangle \mathrm{Ct})$ between the target (BRAF $\left.{ }^{\mathrm{v} 600 \mathrm{e}}\right)$ and a control (wild-type allele [WT]).

\section{Supplemental file 3: Tabulate results of $B R A F^{1600 E}$ allele fraction among sorted sub- populations and per patient.}

Percentage of $B R A F^{\mathrm{V} 600 \mathrm{E}}$ was quantified by $\mathrm{qPCR}$ as described in Supplemental file 2. In subpopulations where $B R A F^{V 600 E}$ levels were close to the limit of detection (i.e. $1 \%$ for monocytes, B lymphocytes, and T lymphocytes; and 5\% for pDCs and $\mathrm{mDCs}$ ), samples were also analyzed by digital PCR using QIAcuity Digital PCR System (Qiagen, Courtaboeuf, France). In these cases, ratio (mutated alleles) / (mutated + WT alleles) and the percentage of the mutated alleles out of the total alleles are reported.

\begin{tabular}{|c|c|c|c|c|c|c|c|c|c|c|}
\hline & \multicolumn{2}{|c|}{ Monocytes } & \multicolumn{2}{|c|}{ pDCs } & \multicolumn{2}{|c|}{ mDCs } & \multicolumn{2}{|c|}{ B lymphocytes } & \multicolumn{2}{|c|}{ T Iymphocytes } \\
\hline & qPCR & $\begin{array}{c}\text { digital } \\
\text { PCR }\end{array}$ & qPCR & $\begin{array}{l}\text { digital } \\
\text { PCR }\end{array}$ & qPCR & $\begin{array}{c}\text { digital } \\
\text { PCR }\end{array}$ & qPCR & $\begin{array}{c}\text { digital } \\
\text { PCR }\end{array}$ & qPCR & $\begin{array}{c}\text { digital } \\
\text { PCR }\end{array}$ \\
\hline P1 & $\begin{array}{c}\text { positive } \\
15 \%\end{array}$ & - & $\begin{array}{c}\text { positive } \\
10 \%\end{array}$ & - & $\begin{array}{c}\text { positive } \\
12 \%\end{array}$ & - & $\begin{array}{c}\text { positive } \\
7 \%\end{array}$ & - & negative & $\begin{array}{c}0 / 1180 \\
(0 \%)^{*}\end{array}$ \\
\hline P2 & $\begin{array}{c}\text { positive } \\
2.5 \% \\
\end{array}$ & - & negative & - & \multicolumn{2}{|c|}{$x$} & $\begin{array}{c}\text { positive } \\
1 \%\end{array}$ & $\begin{array}{c}17 / 1935 \\
(0.9 \%) \\
\end{array}$ & negative & - \\
\hline P3 & $\begin{array}{c}\text { positive } \\
5 \%\end{array}$ & - & $\begin{array}{c}\text { positive } \\
10 \%\end{array}$ & - & $\begin{array}{c}\text { positive } \\
8 \%\end{array}$ & - & $\begin{array}{c}\text { positive } \\
5 \%\end{array}$ & $\begin{array}{c}28 / 707 \\
(4 \%)^{*}\end{array}$ & $\begin{array}{c}\text { positive } \\
1 \%\end{array}$ & $\begin{array}{c}7 / 673 \\
(1 \%)\end{array}$ \\
\hline P4 & $\begin{array}{c}\text { positive } \\
1 \%\end{array}$ & $\begin{array}{c}6 / 681 \\
(0.9 \%) \\
\end{array}$ & negative & - & negative & - & negative & - & negative & - \\
\hline P5 & $\begin{array}{c}\text { positive } \\
1 \%\end{array}$ & $\begin{array}{c}1 / 187 \\
(0.5 \%) \S\end{array}$ & \multicolumn{2}{|c|}{$x$} & \multicolumn{2}{|c|}{$x$} & negative & - & negative & - \\
\hline P6 & \multicolumn{2}{|c|}{$x$} & \multicolumn{2}{|c|}{$x$} & \multicolumn{2}{|c|}{$x$} & negative & $\begin{array}{c}0 / 1625 \\
(0 \%)^{*}\end{array}$ & $\begin{array}{c}\text { positive } \\
2 \%\end{array}$ & $\begin{array}{c}18 / 608 \\
(3 \%)^{*}\end{array}$ \\
\hline
\end{tabular}

Symbol legend:

$\S$ For monocytes of P5, the digital PCR study was hampered by the low quantity of remaining DNA after GPCR analyses. The sample was considered positive with an allelic fraction at $1 \%$ as the sample was positive in all three qPCR assays for this quantification value (all samples were measured in triplicate). * Contols samples used for digital PCR assay: B lymphocytes of P3 and T lymphocytes of P6 were used as positive controls; $B$ lymphocytes of P6 and T lymphocytes of P1 were used as WT controls.

$X$ Due to insufficient amounts of sorted cells, BRAF allele study could not be performed on monocytes for P6, pDCs for P5 and P6, and mDCs for P2, P5 and P6.

_ Digital PCR not done. 


\section{Supplemental file references}

Delhommeau, F., Dupont, S., Tonetti, C., Massé, A., Godin, I., Le Couedic, J.-P., Debili, N., Saulnier, P., Casadevall, N., Vainchenker, W. \& Giraudier, S. (2007) Evidence that the JAK2 G1849T (V617F) mutation occurs in a lymphomyeloid progenitor in polycythemia vera and idiopathic myelofibrosis. Blood, 109, 71-77.

Hélias-Rodzewicz, Z., Funck-Brentano, E., Baudoux, L., Jung, C.K., Zimmermann, U., Marin, C., Clerici, T., Le Gall, C., Peschaud, F., Taly, V., Saiag, P. \& Emile, J.-F. (2015) Variations of BRAF mutant allele percentage in melanomas. BMC cancer, 15, 497.

Levine, R.L., Belisle, C., Wadleigh, M., Zahrieh, D., Lee, S., Chagnon, P., Gilliland, D.G. \& Busque, L. (2006) X-inactivation-based clonality analysis and quantitative JAK2V617F assessment reveal a strong association between clonality and JAK2V617F in PV but not ET/MMM, and identifies a subset of JAK2V617F-negative ET and MMM patients with clonal hematopoiesis. Blood, 107, 4139-4141. 